\title{
Combination of immunostimulants with moxidectin in the treatment of animals experimentally infected with Haemonchus contortus
}

\section{Associação de imunoestimulantes com anti-helmínticos no tratamento de animais experimentalmente infectados com Haemonchus contortus}

\author{
Luiza Pires Portella'; Fagner D'ambroso Fernandes ${ }^{2 *}$; Luís Antônio Sangioni; \\ Fernanda Ramos ${ }^{1}$; Fernando de Souza Rodrigues ${ }^{4}$; Fernanda Rezer de Menezes; \\ Alfredo Skrebsky Cezar6; Tatiane Cargnin Faccin'; Glaucia Denise Kommer;; \\ Fernanda Silveira Flores Vogel ${ }^{3}$
}

Highlights

Antiparasitics and immunostimulants for the treatment of $H$. contortus infection.

Anthelmintic treatment protocols described for $\mathrm{H}$. contortus infection.

Experimental $H$. contortus infection performed in sheep.

\begin{abstract}
Considering the importance of Haemonchus contortus infection in herds along with parasitic resistance, the goal of this study was to evaluate the influence of the administration of adjuvants alone or in combination with anthelmintics for the treatment of $\mathrm{H}$. contortus, in experimentally infected sheep. Thirty sheep of the Texel breed of both genders, raised in a herd located in the subtropical region of Brazil, were used in this experiment. Experimental infection with $H$. contortus was performed in sheep, and the infected sheep were then separated into groups for the administration of antiparasitic and immunostimulant drugs. The results obtained from the excretion of eggs per gram of feces and the count of parasites during necropsy affirm that the use of adjuvants in combination with anthelmintics is associated with higher efficacy of treatment,

1 Phdas in Veterinary Medicine Federal University of Santa Maria, UFSM, Santa Maria, RS, Brazil. E-mail: Iupiresportella@ gmail.com; fernandaramos_7@yahoo.com.br

2 Student, Graduate Program in Veterinary Medicine, UFSM, Santa Maria, RS, Brazil. E-mail: fagnermedvet@gmail.com

3 Profs., Veterinary Medicine Course, Department of Preventive Veterinary Medicine, UFSM, Santa Maria, RS, Brazil. E-mail: lasangioni@gmail.com; glaukommers@yahoo.com; floresfefe14@gmail.com

4 Profs., Veterinary Medicine Course, State University of Londrina, Londrina, PR, Brazil. E-mail: fernando.rodriguesvet@ gmail.com; tatifaccin@hotmail.com

5 Profa., Accounting Sciences Course, Integrated Regional University of Alto Uruguay and Missions, URI, RS, Brazil. E-mail: fernandarezer@gmail.com

6 Prof., Veterinary Medicine Course, Veterinary Medicine Course, Northwestern Regional University of the State of Rio Grande do Sul, UNIJUÍ, RS, Brazil. E-mail: alfredosps@hotmail.com

* Author for correspondence
\end{abstract}

Received: May 27, 2020 - Approved: Oct. 05, 2020 
lower rate of reinfection, and retardation in the development of anthelmintic drug resistance by $\mathrm{H}$. contortus. Based on these results, we can conclude that the combination of anthelmintics and immunostimulants may favor potential anthelmintic treatments for $\mathrm{H}$. contortus.

Key words: Infection. Treatment. Adjuvants. Anthelmintics.

\section{Resumo}

Considerando a importância da infecção por Haemonchus contortus em rebanhos juntamente com a resistência parasitária, o objetivo deste estudo foi avaliar a influência da administração de adjuvantes isolados ou em combinação com o tratamento anti-helmíntico no tratamento de $\mathrm{H}$. contortus em ovinos infectados experimentalmente. Para este trabalho foram utilizados trinta ovinos da raça Texel, de ambos os sexos criados em um rebanho localizado na região subtropical do Brasil. A infecção experimental por $H$. contortus foi realizada nos ovinos, separados em grupos para administração de medicamentos antiparasitários e imunoestimulantes. Os resultados obtidos da excreção de ovos por grama de fezes e da contagem de parasitas durante a necropsia afirmam que o uso de adjuvantes em combinação com anti-helmínticos está associado a maior eficácia do tratamento, menor taxa de reinfecção e retardo do processo de desenvolvimento de resistência anti-helmíntica por $\mathrm{H}$. contortus. Com base nesses resultados, podemos concluir que a combinação de anti-helmínticos e imunoestimulantes podem favorecer potenciais tratamentos anti-helmínticos para $\mathrm{H}$. contortus.

Palavras-chave: Infecção. Tratamento. Adjuvantes. Anti-helmínticos.

\section{Introduction}

Infection with gastrointestinal nematodes is one of the primary sanitary problems in sheep herds (Sczesny-Moraes et al., 2010), causing economic losses to the sheep farming industry. Among the nematodes that infect sheep in Brazil, Haemonchus contortus, a hematophagous parasite with a direct life cycle is the most prevalent and pathogenic strain (Amarante, 2001).

The severity of the disease is directly linked to the number of $H$. contortus larvae present in the abomasum of the host, since there is a strong correlation between blood loss and the number of adult parasites (Le Jambre, 1995). The clinical signs of $H$. contortus infection also depend on other factors such as individual susceptibility, nutritional status, and age of the host (Kotze \& Prichard, 2016). The disease is characterized by severe anemia with paleness of the mucous membranes, submandibular edema, and progressive weight loss. When blood loss exceeds the hematopoietic capacity, haemonchosis can lead to death (Onyiah \& Arslan, 2005; Bowman, 2006).

The control of the spread of these parasites depends on the almost exclusive use of anthelmintics. However, breeding intensification makes this control difficult because there is higher environmental contamination, and consequently, an increase in the rate of infection in the animals, with an increase in the animal stocking rate by area (Thamsborg, Jorgensen, Waller, \& Nansen, 1996). Under such conditions, frequent use of anthelmintic treatments is common, leading to the selection of specific parasitic populations resistant to the active principles available commercially (Kotze \& Prichard, 2016). 
Anthelmintic resistance is a mechanism in which the drug cannot display the same therapeutic efficacy after a certain period, when used under the same conditions (Buzzullini, 2007). Parasitic resistance to anthelmintics is widely disseminated in the multi-resistant populations (Cezar et al., 2010; Bartley et al., 2012; Keane et al., 2014; Martínez-Valladares et al., 2015). Several studies have sought to find alternatives to the use of antiparasitics by attempting to identify and activate natural mechanisms of resistance of the organism and determining ways to select naturally resistant animals (Pugh \& Baird, 2012).

However, the ability to tolerate helminths in the gastrointestinal tract of animals has not been completely elucidated. This ability is a multifactorial feature with genetic, immunological, physiological, and nutritional components, which vary by race and differ between individuals, and is used to determine the three distinct animal biotypes: resistant, sensitive, and resilient (Albers et al., 1987; Amarante, Bricarello, Rocha, \& Gennari, 2004).

H. contortus infection causes inflammation of the abomasal mucosa and activation of the immune system. This leads to the production of cytokines, which are molecules involved in the emission of signals between defense cells and responsible for directing the immune response. Resistant animals have greater efficiency in mounting the Th2 response, while sensitive animals mount the Th1 response (Lawrence, 2003; AlbaHurtado \& Muñoz-Guzmán, 2013; Amarante, 2014).

Therefore, it is essential to search for therapeutic alternatives that enhance the effectiveness of the treatments, delay the process of parasitic resistance, and ensure sustainability of anthelmintic treatment in sheep herds. The stimulus to the immune response can act synergistically with the effect of anthelmintics, thus reducing the parasite burden on animals. Adjuvants are molecules or substances capable of amplifying and prolonging the cascade of immunological events that make up the immune response (Audibert, 2003).

Thus, considering the importance of $H$. contortus infection in herds along with parasitic resistance, the goal of this study was to evaluate the influence of the administration of adjuvants alone or in combination with anthelmintics for the treatment of $H$. contortus in experimentally infected sheep.

Once parasitic resistance is established, the therapeutic efficacy of most conventional anthelmintics is either compromised or ineffective in the long term. This framework tends to evolve dramatically, if specific measures are not taken to decelerate or cure the infection. Therefore, it is crucial to resort to pharmacological alternatives to improve the effectiveness of anthelmintic treatments and ensure its sustainability, thereby improving the life of animals affected by multi-resistant gastrointestinal nematodes. Modulation of the immune response could be a potential alternative to prevent drug resistance (Quinn, 1990; ArunKumar, Abdul Basith, \& Gomathinayagam, 2012).

\section{Materials and Methods}

\section{Location and animals}

Thirty sheep of the Texel breed of both genders aged 6-8 months were used for the study. The sheep were individually identified with numbered earrings and were raised in a 
herd located in the subtropical region of Brazil. The animals were housed in collective stalls with five animals in each stall, and all the animals remained in the same shed throughout the experimentation period. All the animals were fed the same diet that included approximately $14 \%$ protein. The animals were maintained for a period of 20 days, where they were treated with Zolvix ${ }^{\circledR}$ (Monepantel) (Novartis Animal Health, $2.5 \mathrm{mg} / \mathrm{kg}$ ) for the elimination of parasite load. Water was supplied ad libitum in the suspended buckets.

The procedures involving the use of animals (sample collection, anthelmintic treatments, identification, body weighting, and general management) were submitted and approved by the Animal Experimentation Ethics Committee of the Federal University of Santa Maria, under protocol number 8088190815

\section{Production of $\mathrm{H}$. contortus larvae and experimental infection}

Infective larvae (L3) cultures of $H$. contortus were used for experimental infection in the animals. Fecal samples were collected directly from the rectum of the monoinfected donor animals, according to the protocol described by the Laboratory of Parasitology of UNESP's Bioscience Institute, Botucatu campus, under the supervision of Dr. Alessandro Francisco Talamine do Amarante. The infective larvae (L3) were obtained as described by Roberts and O'Sullivan (1950). Coproparasitological examinations were performed for all the lambs to verify that they were negative for $H$. contortus before experimental infection.
The animals were orally administered thrice, at an interval of two days, with thirdstage larvae diluted in distilled water. The weight of the animal determined the number of larvae to be administered (Fausto et al, 2014). For each kilogram of the animal live-weight, 300 third-stage larvae were administered. The first day of infection was established as day 0 of experimental infection (D0) and after 14 days (D14), the animals were reinfected.

\section{Experimental groups}

Thirty animals (five animals per group) were individually weighed on a digital scale for the accuracy of the doses to be administered. The administration of adjuvants and active ingredients were standardized, for monitoring the possible changes in the region of administration. All treatments were performed individually. Moxidectin (Mox) and aluminum hydroxide $\left(\mathrm{Al}(\mathrm{OH})_{3}\right) \mathrm{gel}$ were administered subcutaneously, while a suspension of lipopolysaccharide (LPS) and Propionibacterium acnes (LPS $+P$. acnes) was administered intramuscularly. All animals remained under observation for $60 \mathrm{~min}$ after the treatments to evaluate possible clinical changes. The treatment groups were as follows: G1 control (distilled water), G2 (Mox), $\mathrm{G} 3\left(\mathrm{Mox}+\mathrm{Al}(\mathrm{OH})_{3}\right), \mathrm{G} 4\left(\mathrm{Al}(\mathrm{OH})_{3}\right), \mathrm{G} 5(\mathrm{Mox}+(\mathrm{LPS}$ + P. acnes), and G6 (LPS + P. acnes).

\section{Antiparasitic drug and immunostimulants}

Moxidectin (1\%) (Cydectin $^{\circledR}$, Zoetis Industria de Produtos Veterinários Ltda. Campinas-SP, Brazil) was administered subcutaneously at a dose of $0.2 \mathrm{mg} / \mathrm{kg}$, as 
indicated by the manufacturer. This drug was chosen for antiparasitic testing since it was found ineffective in a previous experiment (Amarante, Garcia, Togerson, \& Amarante, 2010). The adjuvants tested in combination with moxidectin were as follows: $100 \mu \mathrm{g} / \mathrm{mL} \mathrm{Al}(\mathrm{OH})_{3}$ gel at a dose of $0.04 \mathrm{~mL} /$ animal (subcutaneous route) and LPS $+P$. acnes (Infervac ${ }^{\circledR}$, Calier SA, Barcelona, Spain) at a dose of $0.025 \mathrm{mg} / \mathrm{kg}$ (intramuscular route).

\section{FAMACHA and sample collection}

The ocular mucosa of all the animals was evaluated on the following days: D0, D7, D14, D21, D28, and D35. The evaluation was carried out by examining the different colors of the conjunctiva, from pinkish red to pale white, represented by the numbers 1 to 5 , and by comparing with the guide card used in the field (Molento et al., 2004). In addition, a general evaluation revealed no clinical signs for the presence of submandibular edema and diarrhea. Blood samples were collected by jugular vein puncture and stored in vacutainers with EDTA. Simultaneously, fecal samples were collected from the rectum, packed in individual plastic bags, labeled, and refrigerated until further processing.

\section{Blood processing and parasitological examinations}

Hematocrit was determined using the microhematocrit technique. Blood was collected in capillary tubes $(75 \times 1 \mathrm{~mm})$, filled up to two-thirds of their total volume, labeled, and placed in a microcentrifuge at 10,000 rpm for 5 min.
Two blood smears were prepared for differential leukocyte counting. After drying, these smears were dyed using the fast dye. The smears were observed under a microscope (1000x magnification), and 100 leukocytes were classified into neutrophils, eosinophils, basophils, lymphocytes, and monocytes, based on their morphological and staining characteristics. To obtain EPG counts, the McMaster modified technique was performed with a sensitivity of 100 EPG. Prior to treatment, the animals were distributed into six randomized blocks based on the EPG count and weight. Animals that had an EPG count $\geq$ 500 on D2 were selected for treatment.

For post-treatment analysis, EPG of the larval culture was performed using the modified McMaster technique with an EPG count $\geq 500$.

For the larval culture preparation, feces from all sheep were pooled, mixed with sterile wood shavings, and stored for further analysis (moisturized daily with sterile water on days D7, D14, D21, D28, and D35). These stored larval cultures were incubated for 7 days at $22-27^{\circ} \mathrm{C}$ and $80 \%$ humidity, according to the recommendations of Coles et al. (1992). After incubation, the larvae were recovered by baermanization, and 100 third-stage larvae in each culture were identified (by genera) following the criteria described by Van Wyk and Mayhew (2013).

\section{Necropsy of the animals}

At D21 after reinfection (D35), five animals from each group were euthanized with intravenous injections of $10 \mathrm{mg} 2 \%$ acepromazine, $2 \mathrm{~g}$ thiopental sodium, and 100 
$\mathrm{mL}$ potassium chloride, and the abomasum was examined to quantify the number of adult parasites (L5). After opening the abomasum at the major curvature, the organ was carefully washed with $1 \mathrm{~L}$ of water, and the entire content was collected. The contents were homogenized and an aliquot of $100 \mathrm{~mL}$ was prepared for parasite counting, as recommended by the World Association for the Advancement of Veterinary Parasitology.

\section{Eosinophil tissue counting}

The abomasum was washed, and its fragments were collected to count eosinophil tissues. Samples from the abomasal fundus area were sectioned, fixed in $10 \%$ formaldehyde for $24 \mathrm{~h}$, and embedded in paraffin. The sections were stained with hematoxylin-eosin for subsequent counting of eosinophils. The methodology for obtaining the number of eosinophils was based on the quantification of the totality of these cells obtained in 10 random fields focused from the muscular layer to the surface of the mucosa, by increasing the magnification to $400 \times$. The individual counting results were expressed as an average of the number of eosinophils.

\section{Statistical analysis}

The efficacy of each treatment was estimated based on the fecal egg count reduction test, using the pre- and posttreatment EPG counts for each group (Neves, Carvalho, Rinaldi, Gringoli, \&Amarante, 2014).
A Tukey test with a 95\% confidence interval was performed for statistical analysis of the data obtained from FAMACHA, hematocrit, leukocytes, larval counts, and tissue eosinophil counts.

\section{Results}

The average efficacy of the different treatments/groups on D7, D14, D21, D28, and D35 is shown in Table 1. In G3, where the animals received $1 \% \mathrm{Mox}+\mathrm{Al}(\mathrm{OH})_{3^{\prime}}$ treatment efficacy was as follows: D14 (95\%), D21 (99\%), D28 (98\%), and D35 (100\%). In G5, where animals received $1 \%$ Mox $+($ LPS $+P$. acnes), the animals showed an improvement in the treatment efficacy on D14 (93\%), D21 (95\%), D28 (97\%), and D35 (100\%). Furthermore, reinfection evaluated on D35 was higher in G2 than in G3 and G5. According to the criteria proposed by WAAVP [22], on D7 of the experiment, no group showed high treatment efficacy, among which, the highest efficacy of $79 \%$ was observed in the Mox + (LPS + P. acnes)-treated group. The animals evaluated on D14 showed an efficacy of $95 \%$ for the Mox $+\mathrm{Al}(\mathrm{OH})_{3}$-treated group, followed by $93 \%$ for the Mox + (LPS $+P$. acnes)-treated group. On D21, treatments with Mox, Mox $+\mathrm{Al}(\mathrm{OH})_{3}$, and Mox + (LPS + P. acnes) presented desirable efficacy results of $96 \%$, $99 \%$, and $95 \%$, respectively. 
Table 1

Efficacy of treatment in sheep experimentally infected with $H$. contortus on different days after treatment

\begin{tabular}{lccccc}
\multicolumn{1}{c}{ Groups $(\mathrm{n}=5)$ and treatments } & \multicolumn{5}{c}{ Efficacy $(\%)$} \\
\cline { 2 - 6 } G2. Mox & Day 7 & Day 14 & Day 21 & Day 28 & Day 35 \\
G3. Mox $+\mathrm{Al}(\mathrm{OH})_{3}$ & 65 & 85 & 96 & 97 & 90 \\
G4. Al(OH) $)_{3}$ & 68 & 95 & 99 & 98 & 100 \\
G5. Mox $+(\mathrm{LPS}+P$. acnes) & 61 & 72 & 59 & 87 & 100 \\
G6. LPS + P. acnes & 79 & 93 & 95 & 97 & 100
\end{tabular}

Upon evaluation of reinfection on D28, the highest treatment efficacy was observed in the Mox, Mox $+\mathrm{Al}(\mathrm{OH})_{3^{\prime}}$ and Mox + (LPS $+P$. acnes) groups $(97 \%, 98 \%$, and $97 \%$, respectively). However, evaluation on D35 showed $100 \%$ efficacy in the Mox $+\mathrm{Al}(\mathrm{OH})_{3^{\prime}}$ $\mathrm{Al}(\mathrm{OH})_{3^{\prime}}$ and Mox + (LPS + P. acnes) groups. No statistical differences were observed between the groups evaluated for FAMACHA, hematocrit, leukocytes, leukocyte differential, and eosinophil counts in the abomasal mucosa, and remained within the normality presented in the literature for the species.

The total parasite count of the aliquot obtained from the abomasum after washing the euthanized sheep is displayed in Table 2.
These results revealed that only the control group showed a high population of parasites, whereas all the other groups treated with the anthelmintic, adjuvant, or both showed low parasite count.

Hematocrit and FAMACHA evaluations revealed no statistical differences between the treated and untreated groups $(p>$ 0.05). The parasite count revealed that the animals subjected to anthelmintic and immunostimulant treatments had a low larval count with statistical differences $(p<0.05)$ from the control group, which presented the highest larval count. Clinical evaluation reported the absence of submandibular edema and diarrhea in the animals.

\section{Table 2}

\section{Parasite count of the samples collected from the abomasum after washing}

\begin{tabular}{|c|c|}
\hline \multirow{2}{*}{ Groups ( $n=5$ ) } & Parasite count \\
\hline & H. contortus \\
\hline G1. Cont & 206 \\
\hline G2. Mox & 5 \\
\hline $\mathrm{G} 3 . \mathrm{Mox}+\mathrm{Al}(\mathrm{OH})_{3}$ & 0 \\
\hline $\mathrm{G} 4 . \mathrm{Al}(\mathrm{OH})_{3}$ & 9 \\
\hline G5. Mox + (LPS + P. acnes) & 1 \\
\hline G6. LPS + P. acnes & 8 \\
\hline
\end{tabular}


Although these data do not present statistical differences because of the small number of animals available for analysis, they strongly suggest that the combination of antiparasitics with immunostimulants can reduce and/or eliminate nematode infection of the GI tract and prevent reinfection.

\section{Discussion}

There are several reports on the parasitic resistance to moxidectin (Love, Nielson, Biddle, \& Mckinnon, 2003; Howell et al., 2008). In Brazil, a study reported approximately $80 \%$ resistance to moxidectin (Cunha, Pereira, \& Yamamura, 1998). Another study reported $51 \%$ efficacy of moxidectin upon evaluation in the regions of Londrina, Paraná (Buzzulin, Costa, Santos, Borges, \& Soares, 2007), Jaboticabal, São Paulo (Rosalinski-Moraes et al., 2007), and Santa Catarina, in addition to other studies conducted in these regions (Cezar et al., 2010). Another study conducted in the same region reported approximately $45 \%$ efficacy of moxidectin (Almeida, Garcia, Torgerson, \& Amarante, 2010), whereas a study conducted in São Paulo reported an efficacy of 95\% (Nagata et al., 2019).

The failure of anthelmintic treatments increases the parasitic load in animals and contaminates the pastures due to eggs and larvae deposition. Under such conditions, the producers often alter the prescribed course of antiparasitic treatments, such as increasing the frequency of treatments, use of drugs with high concentration (with longer action), and rapid alternation of chemical bases. However, this results in greater selection pressure and rapid development of parasitic resistance, reduction of shelter, and increased environmental contamination by drug residues. Additionally, it results in greater risk of deposition of these residues in products intended for human consumption, and increased costs of treatments without the proportional improvement of its effectiveness that consequently results in total suspension of anthelmintic control in the sheep herds (Cezar et al., 2010).

The immune response against nematodes mainly involves the recognition and processing of parasitic antigens, action of CD4 + Th2 lymphocytes, increase in the number of inflammatory cells in the mucosa and circulating eosinophils, production of specific antibodies, and increase in mucus production with inhibitory substances (Hohenhaus \& Outteridge, 1995). Immunostimulants can stimulate the non-specific immune responses and are usually administered to prevent the generalresistanceinanimals, whichareexposed to the risk of infection (Quinn, 1990). The use of the two adjuvants in the non-associated form reduced the infection rate of the animals as well as reinfection (evaluated mainly at D35 pi). It was observed that the groups treated with immunostimulants alone (G4 and G6) had a reduction in OPG counts on D7, D14, D21, D28, and D35, with the best results on D28 $(87 \%$ and $85 \%$ for G4 and G5, respectively) and D35 (100\% and $84 \%$ for G4 and G5, respectively). This data corroborates with Abel et al. (2009), who used LPS-based compound adjuvants and $P$. acnes in experimental models infected with nematodes and observed a significant reduction in the infection rate. This reduction is probably associated with the proliferation of $T$ lymphocytes and an increase in the number of eosinophils.

Based on this evidence, it was expected that the combination of immunostimulants with an antiparasitic effect could provide 
better efficacy. The results obtained in our study prove this hypothesis. In the groups treated with moxidectin and the adjuvants, improvement in the efficacy of the treatment was observed. We observed higher efficacy with reduced parasite counts in the groups that received anthelmintic administration along with immunostimulants than in those administered with either drugs alone. Although these results did not show statistical differences, we strongly suggest the use of a combination of immunostimulants with anthelmintics in antiparasitic treatments for nematode infections. Martins et al. (2012) studied a group of sheep treated with antiparasitics and another group treated with antiparasitics combined with immunostimulants and found no significant differences in the EPG values, although lower values were observed in all samples treated with the combination.

It is known that the use of immunostimulants is associated with neutrophilia, eosinophilia, and an increase in the response of $\mathrm{T}$ and $\mathrm{B}$ lymphocytes, along with changes in the bone marrow activity (Pappaterra Mendoza et al., 2000). An increase in the number of eosinophils or immunoglobulin $E$ (IgE) levels has a negative correlation with the number of OPG found in the animals (Kooyman et al., 1997), thus indicating a certain antiparasitic resistance in sheep (Shakya, Miller, \& Horohov, 2009). However, in this study, no statistical differences were detected in blood and tissue eosinophil counts between the experimental groups.

The reduction in egg count per gram of feces and reinfection is associated with the immunostimulatory effect of the adjuvants. Braga et al. (2003) demonstrated the effect of $P$. acnes in the modulation of the immune response and characterized this late-acting adjuvant, which justifies the gradual increase in treatment efficacy. The same was observed in animals receiving Mox $+\mathrm{Al}(\mathrm{OH})_{3}$ treatment (G3).

A study conducted by Stear, Bairden, Duncan and Murray (1995) demonstrated that animals may present different hematological behaviors upon recurrent $H$. contortus infections. The first infection may have a marked decrease in red blood cells; however, these animals recover and the parameters continue to improve after the second and third infections. At the end of 23 weeks, the number of red blood cells in the treated and untreated groups was found to be the same.

In addition to OPG, necropsy is an important factor for revealing the major nematode lesions as well as the number and species of parasites present in the animal (Climeni, Monteiro, Cicoti, \& Neves, 2008).

Although OPG is still the most widely used technique in this field, parasitological necropsy is a highly important factor because of the density-dependent phenomenon of $H$. contortus (Cezar etal., 2010; Domke etal., 2012; Mitchell, Hunt, Wood, \& McLean, 2010; Pivoto et al., 2014; Santos et al., 2014). However, the sensitivity of this technique is limited due to the characteristic of ovines with high parasitic load to produce feces with little or no eggs of the parasite. This is because the $H$. contortus females cease egg production in the presence of high parasitic load in the abomasum of the animals (Zajac, 2006).

\section{Conclusion}

The results obtained from the excretion of eggs per gram of feces and the count of parasites at necropsy suggest that the use of adjuvants combined with anthelmintics is 
associated with higher efficacy of treatment, lower rate of reinfection, and retardation in the development of anthelmintic drug resistance in $H$. contortus. Therefore, an improvement in the efficacy of drugs to prevent the development of multi-resistant parasites is extremely important for the maintenance of sheep health. Development and commercialization of anthelmintic drugs combined with adjuvants is a potential strategy to improve the quality of sheep life and prevent drug resistance.

\section{Author Contributions}

All the authors contributed equally to the manuscript.

\section{References}

Abel, L. C. J., Chen, S., Ricca, L. G., Martins, M. F., Garcia, M., Ananias, R. Z.,... LongoMaugéri, I. M. (2009). Adjuvant effect of LPS and killed Propionibacterium acnes on the development of experimental gastrointestinal nematode infestation in sheep. Parasite Immunology, 31, 604-612. doi: 10. 1111/j.1365-3024.2009.01132.x

Alba-Hurtado, F., \& Muñoz-Guzmán, M. A. (2013). Immune responses associated with resistance to haemonchosis in sheep. BioMed Research International, 2013, 1-11. doi: 10.1155/2013/162158

Albers, G. A. A., Gray, G. D., Piper, L. R., Barker, J. S. F., Jambre, L. F., \& Barger, I. A. (1987) The genetics of resistance and resilience to Haemonchus contortus infection in young Merino sheep. International Journal of Parasitology, 17(7), 1355-1363. doi: 10.1016/0020-7519(87)90103-2
Almeida, F. A., Garcia, K. C., Torgerson, P. R., \& Amarante, A. F. T. (2010). Multiple resistance to anthelmintics by Haemonchus contortus and Trichostrongylus colubriformis in sheep in Brazil. Parasitology International, 59, 622625. doi: 10.1016/j.parint.2010.09.006

Amarante, A. F. T. (2001). Controle de endoparasitoses dos ovinos. In W. R. S. Mattos (Ed.), A produção animal na visão dos brasileiros (pp. 461-473). Piracicaba: Fealq/SBZ.

Amarante, A. F. T. (2014). Os parasitas de ovinos. São Paulo: Editora UNESP.

Amarante, A. F. T., \& Amarante, M. R. V. (2003). Breeding sheep for resistance to nematode infections. Journal of Animal and Veterinary Advances, 2(3), 147-161. doi: 10.1079/9781845935559.0279

Amarante, A. F. T., Bricarello, P. A., Rocha, R. A., \& Gennari, S. M. (2004). Resistance of Santa Ines, Suffolk and lle de France sheep to naturally acquired gastrointestinal nematode infections. Veterinary Parasitology, 120(1), 91-106. doi: 10.1016/j.vetpar.2003.12.004

Amarante, F. A., Garcia, K. C., Togerson, P. R., \& Amarante, A. F. T. (2010). Multiple resitence to anthelmintics by Haemonchus contortus and Trichostrongylus colubriformis in sheep in Brazil. Parasitology International, 59, 622625. doi: 10.1016/j.parint.2010.09.006

ArunKumar, S., Abdul Basith, S., \& Gomathinayagam, S. (2012). A comparative analysis on serum antibody levels of sheep immunized with crude and thiol-purified excretory secretory antigen of Haemonchus contortus. Veterinary World, 5(5), 279-284. doi: 10.5455/ vetworld.2012.279-284 
Audibert, F. (2003). Adjuvants for vaccines, a quest. International Immunopharmacology, 3, 1187-1193. doi: 10.1016/S1567-5769(03)00011-0

Bartley, D. J., Mcarthur, C. L., Devin, L. M., Sutra, J. F., Morrison, A. A., Lespine, A., \& Matthews, J. B. (2012). Characterization of macrocycliclactone resistanceintwo fieldderived isolates of Cooperia oncophora. Veterinary Parasitology, 190, 454-460. doi: 10.1016/j.vetpar.2012.07.022

Bowman, D. D. (2006). Parasitologia veterinária de Georgis (8a ed.). Barueri: Manole.

Braga, E. G., Ananias, R. Z., Mussalem, J. S., Squaiella, C. C., Longhini, A. L. F., Mariano, M.,... Longo-Maugéri, I. M. (2003). Treatment with Propionibacterium acnes modulates the late phase reaction of immediate hypersensitivity in mice. Immunology Letters, 88(2), 163-169. doi: 10.1016/S0165-2478(03) 00079-8

Buzzulin, C., Costa, A. J., Santos, T. R., Borges, F. A., \& Soares, V. E. (2007). Eficácia antihelmíntica comparativa da associação albendazole, levamisole e ivermectina à moxidectina em ovinos. Pesquisa AgropecuáriaBrasileira, 42(6),891-895.doi: 10.1590/S0100-204X2007000600017

Cezar, A. S., Toscan, G., Camillo, G., Sangioni, L. A., Ribas, H. O., \& Vogel, F. S. F. (2010). Multiple resistance of gastrointestinal nematodes to nine different drugs in a sheep flock in southern Brazil. Veterinary Parasitology, 173, 157-160. doi: 10.1016/j. vetpar.2010.06.013

Climeni, B. S. O., Monteiro, M. V., Cicoti, C. A., \& Neves, M. F. (2008). Hemoncose ovina. São Paulo: Editora FAEF.
Coles, G. C., Coles, G. C., Bauer, C., Borgsteede, F. H. M., Geerts, S., Klei, T. R.,... Waller, P. J. World Association for the Advancement of Veterinary Parasitology (WAAVP) methods for the detection of anthelmintic resistance in nematodes of veterinary importance. Veterinary Parasitology, 44, 35-44. doi: 10.1016/0304-4017(92)90141-U

Cunha, L. F. C. D., Fo., Pereira, A. B. D. L., \& Yamamura, M. H. (1998). Resistência a anti-helmínticos em ovinos da região de Londrina - Paraná - Brasil. Semina: Ciências Agrárias, 19(1), 31-37.

Domke, A. V., Chartier, C., Gjerde, B., Höglund, J., Leine, N., Vatn, S., \& Stuen, S. (2012) Prevalence of anthelmintic resistance in gastrointestinal nematodes of sheep and goats in Norway. Parasitology Research, 111, 185-193. doi: 10.1007/s00436-0122817-x

Fausto, G. C., Pivoto, F. L., Costa, M. M., Lopes, S. T. A., França, R. T., Molento, M. B.,... Leal, M. L. R. (2014). Protein profile of lambs experimentally infected with Haemonchus contortus and supplemented with selenium and copper. Parasites \& Vectors, 7355. doi: 10.1186/1756-3305-7-355

Hohenhaus, M. A., \& Outteridge, P. M. (1995). The immunogenetics of resistance to Trichostrongylus colubriformis and Haemonchus contortus parasites in sheep. British Veterinary Journal, 151, 119-141. doi: 10.1016/S0007-1935(95)80004-2

Howell, S. B., Burke, J. M., Miller, J. E., Terrill, T. H., Valencia, E., Williams, M. J.,... Kaplan, R. M. (2008). Prevalence of anthelmintic resistance on sheep and goat farms in the southeastern United States. Journal of the American Veterinary Medical Association, 233(12), 1913-1919. doi: 10.2460/javma. 233.12.1913 
Keane, O. M., Keegan, J. D., Good, B., Waal, T., Fanning, J., Gottstein, M.,... Sheehan, M. (2014). High level of treatment failure with commonly used anthelmintics on Irish sheep farms. Irish Veterinary Journal, 67, 16. doi: 10.1186/2046-0481-67-16

Kooyman, F. N., Van Kooten, P. J., Huntley, J. F., Mackellar, A., Cornelissen, A. W., \& Schallig, H. D. (1997). Production of a monoclonal antibody specific for ovine immunoglobulin $E$ and its application to monitor serum $\operatorname{lgE}$ responses to Haemonchus contortus infection. Parasitolology, 114, 395-406. doi: 10. 1017/S0031182096008633

Kotze, A. C., \& Prichard, R. K. (2016). Chapter nine - anthelmintic resistance in Haemonchus contortus: history, mechanisms and diagnosis. Advances in Parasitology, 93, 397-428. doi: 10.1016/ bs.apar.2016.02. 012

Lawrence, C. E. (2003). Is there a common mechanism of gastrointestinal nematode expulsion? Parasite Immunology, 25, 271281. doi: 10.1046/j.1365-3024.2003.006 30.x

Le Jambre, L. F. (1995). Relationship of blood loss to worm numbers, biomass and egg production in Haemonchus infected sheep. International Journal of Parasitology, 25(3), 269-273. doi: 10.1016/ 0020-7519(94)00118-8

Love, S., Neilson, F., Biddle, A. J., \& Mckinnon, R. (2003). Moxidectin-resistant Haemonchus contortus in sheep in northern New South Wales. Australian Veterinary Journal, 81(6), 359-360. doi: 10.1111/j.1751-0813. 2003.tb11514.x
Martins, S. M. F. M., Garcia, M., Chate, S. C., Tavolari, F. A., Teixeira, R. B. C., Matins, L. R., Jr.,... Abel, L. J. (2012). (2012). Association of immunostimulant with anthelmintic on the treatment of sheep verminosis. Ciência Rural, 4(12), 2229-2234. doi: $10.1590 / S 0103-84782012005000142$

Martínez-Valladares, M., Geurden, T., Bartram, D. J., Martínez-Pérez, J. M., Robles-Pérez, D., Bohórquez, A.,... Rojo-Vázquez, F. A. (2015). Resistance of gastrointestinal nematodes to the most commonly used anthelmintics in sheep, cattle and horses in Spain. Veterinary Parasitology, 211, 228233. doi: 10.1016/ j.vetpar.2015.05.024

Mitchell, E. S. E., Hunt, K. R., Wood, R., \& McLean, B. (2010). Anthelmintic resistance on sheep farms in wales. Veterinary Record, 166, 651-652. doi: 10.1136/vr.b4840

Molento, M. B., Tasca, C., Gallo, A., Ferreira, M., Bononi, R., \& Stecca, E. (2004). Método Famacha como parâmetro clínico individual de infecção por Haemonchus contortus em pequenos ruminantes. Ciência Rural, 34(4), 1139-1145.

Nagata, W. B., Panegossi, M. F. C., Bresciani, K. D. S., Gomes, J. F., Kaneto, C. N., \& Perri, S. H. (2019). Resistance of gastrointestinal nematodes to five different active principles ins sheep infected naturally in São Paulo State, Brazil. Small Ruminant Research, 172, 48-50. doi: 10.1016/j. smallrumres.2018.10.001

Neves, J. H. D., Carvalho, N., Rinaldi, L., Gringoli, G., \& Amarante, A. F. T. (2014). Diagnosis of anthelmintic resistance in cattle in Brazil: a comparison of different methodologies. Veterinary Parasitology, 206, 216-226. doi: 10.1016/j.vetpar.2014.10.015 
Onyiah, L. C., \& Arslan, O. (2005). Simulating the development period of a parasite of sheep on pasture under varying temperature conditions. Journal of Thermal Biology, 30, 203-211. doi: 10.1016/j.jtherbio.2004. 10.003

Pappaterra Mendoza, G. J., Mateu de Antonio, E., Novel Badal, M. E., Castillo, M. M., Fábrega, J. C., \& Puig, J. M. (2000). In vitro and in vivo effects of an immunomodulator composed of Escherichia coli lipopolysaccharide and Propionibacterium granulosum -inactivated cells in pigs. Journal of Veterinary and Medicine $B$, Infectious Diseases and Veterinary Public Health, 47, 619-627. doi: 10.1046/j.143904 50.2000.00395.x

Pivoto, F. L., Machado, F. A., Nezi, P. A., Jr., Weber, A., Cezar, A. S., Sangioni, L. A., \& Vogel, F. S. F. (2014). Improving liveweight gain of lambs infected by multidrugresistant nematodes using a FECRT-based schedule of treatments. Parasitology Research, 113, 2303-2310. doi: 10.1007/ s00436-014-3885-x

Pugh, D. G., \& Baird, A. N. (2012). Sheep and goat medicine (2nd ed.). Saunders: Maryland Heights.

Quinn, P. J. (1990). Mechanisms of action of some immunomodulators used in veterinary medicine. Advances in Veterinary Science and Comparative Medicine, 35, 43-99. doi: 10.1016/B9780-12-0392 35-3.50009-5

Roberts, F. H. S., \& O'Sullivan, P. J. (1950). Methods for eggs counts and larval cultures for strongyles infecting the gastrointestinal tract of catlle. Australian Journal Agriculture Research, 1(1), 99-102.
Rosalinski-Moraes, F., Moretto, L. H., Bresolin, W. S., Gabrielli, I., Kafer, L., Zanchet, I. K.,... Thomaz-Soccol, V. (2007). Resistência antihelmíntica em rebanhos ovinos da região da Associação dos Municípios do Alto Irani (AMAl), Oeste de Santa Catarina. Ciência Animal Brasileira, 8(3), 559-565. doi: 10.5216/cab.v8i3.1733

Santos, J. M., Monteiro, J. P., Ribeiro, W. L. C., Macedo, I. T. F., Camurça-Vasconcelos, A. L. F., Vieira, L. S., \& Bevilaqua, C. M. L. (2014). Identification and quantification of benzimidazole resistance polymorphisms in Haemonchus contortus isolated in Northeastern Brazil. Veterinary Parasitology, 199, 160-164. doi: 10.1016/j. vetpar.2013.11.006

Sczesny-Moraes, E. A., Bianchin, I., Silva, K. F., Catto, J. B., Honer, M. R., \& Paiva, F. (2010). Resistência anti-helmíntica de nematóides gastrintestinais em ovinos, Mato Grosso do Sul. Pesquisa Veterinária Brasileira, 30(3), 229-236. doi: 10.1590/ S0100-736X2010000300007

Shakya, K. P., Miller, J. E., \& Horohov, D. W. (2009). A Th2 type of immune response is associated with increased resistance to Haemonchus contortus in naturally infected Gulf Coast Native lambs. Veterinary Parasitology, 163, 57-66. doi: 10.1016/j.vetpar.2009.03.052

Stear, M. J., Bairden, K., Duncan, J. L., \& Murray, M. (1995). A comparison of the responses to repeated experimental infections with Haemonchus contortus among Scottish Blackface lambs. Veterinary Parasitology, 60, 69-81. doi: 10.1016/0304-4017(94) 00776-9 
Thamsborg, S. M., Jorgensen, R. J., Waller, P. J., \& Nansen, P. (1996). The influence of stocking rate on gastrointestinal nematode infections of sheep over a 2-year grazing period. Veterinary Parasitology, 67, 207-224. doi: 10.1016/ S0304-4017(96)01045-X

Van Wyk, J. A., \& Mayhew, E. (2013). Morphological identification of parasitic nematode infective larvae of small ruminants and cattle: a practical lab guide. Journal of Veterinary Research, 80(1), 539. doi: 10. 4102/ojvr.v80i1.539
Zajac, A. M. (2006). Gastrointestinal nematodes of small ruminants: life cycle, anthelmintics, and diagnosis. Veterinary Clinics of North America: Food Animal Practice, 22(3), 529-541. doi: 10.1016/j.cvfa.2006. 07.006 